of August 31, 1810 at Terre Blanche, was in present Alberta.

Gary W. Seib and Gary Anweiler have both called my attention to a serious error in the caption depicting the University of Saskatchewan, Saskatoon campus, Biology museum specimen on page 80 of the June Blue Jay article. This was stated to be "the only specimen in Saskatchewan," but Seib and Anweiler called to my attention the presence of Passenger Pigeon specimens in the Swift Current Museum and the Saskatchewan Museum of Natural History, Regina.

Mrs. Clarence Wilson, curator of the Swift Current Museum, writes that their specimen, dating from about 1886, was donated in more recent years by Charles Warren. It had been given to his father, George Warren of Swift Current, by Police Chief Jarvis of Bowmanville, Ontario, about 1910.

M. K. Baker, Director of the Saskatchewan Museum of Natural History, wrote to explain the absence of their two Passenger Pigeon specimens from the annual museum accession lists. In fact, these two specimens have not been accessioned and hence no information concerning them is available, except that they are believed to be from Ontario.

\title{
NOTES ON A CAPTIVE POOR-WILL IN ALBERTA
}

\section{by Loran L. Goulden, Biochemistry, University of Alberta, Edmonton}

The purpose of this article is not to encourage the taking in or capturing of birds that could survive when left alone, but to report on an interesting house guest. On October 27, 1971, Mr. and Mrs. John Hostvedt, who farm near Lindberg, about 165 miles northeast of Edmonton, found by the doorstep of their house, a Poor-will (Phalaenoptilis nuttallii) that appeared to be sluggish. After taking the bird inside and finding that it became active, they released it. Three days later, however, it was back on their doorstep and since it was now cold outdoors and snowing, the Hostvedts decided to let it stay in their home (Lister, 1972).

The only authenticated record of the Poor-will in Alberta is of one collected in the Cypress Hills area of southeastern Alberta in 1945 (Salt and Wilk, 1966) a region about 350 miles south of the Hostvedt farm. The bird normally winters from central California, southern Arizona, and Texas south to central Mexico (Reilly, 1968). According to Godfrey (1966), it breeds from southern interior British Columbia, southern Alberta, northwestern South Dakota, and southwestern Iowa south (on the Pacific Coast from central California to southern Baja Cali- fornia) and through eastern Kansas and central Texas to central Mexico. $\mathrm{He}$ adds that it probably breeds in southwestern Saskatchewan (Calf Creek). The basis for this last statement was provided by a collected specimen (Bard, 1961). A second collection was made in the same area in 1964 (Beck, 1965). Elliott states (1966) that the known range of the Poor-will in Saskatchewan includes areas ranging in climate from very hot and dry, such as the Great Sand Hills and the Frenchman Valley, to relatively cool and humid, like the Cypress Hills.

That the Poor-will "hibernates" during the winter in the northern part of its range has been known for some time. In 1946 Jaeger ('48, '49, '53) found a Poor-will in a torpid state in the Chuckawalla Mountains near the southeast tip of California, midway in the Colorada Desert between Salton Sea and the Colorado River. $\mathrm{He}$ observed it for three years as it came back to the same spot each year. One winter it slept without food for 88 days. The temperature of its body was as low as $64.4^{\circ} \mathrm{F} \quad\left(18^{\circ} \mathrm{C}\right)$, never above $67^{\circ} \mathrm{F}\left(19.4^{\circ} \mathrm{C}\right)$. The normal temperature of an active Poor-will is known to be about $106^{\circ} \mathrm{F}\left(41^{\circ} \mathrm{C}\right)$.

Culbertson (1952) mentions finding 


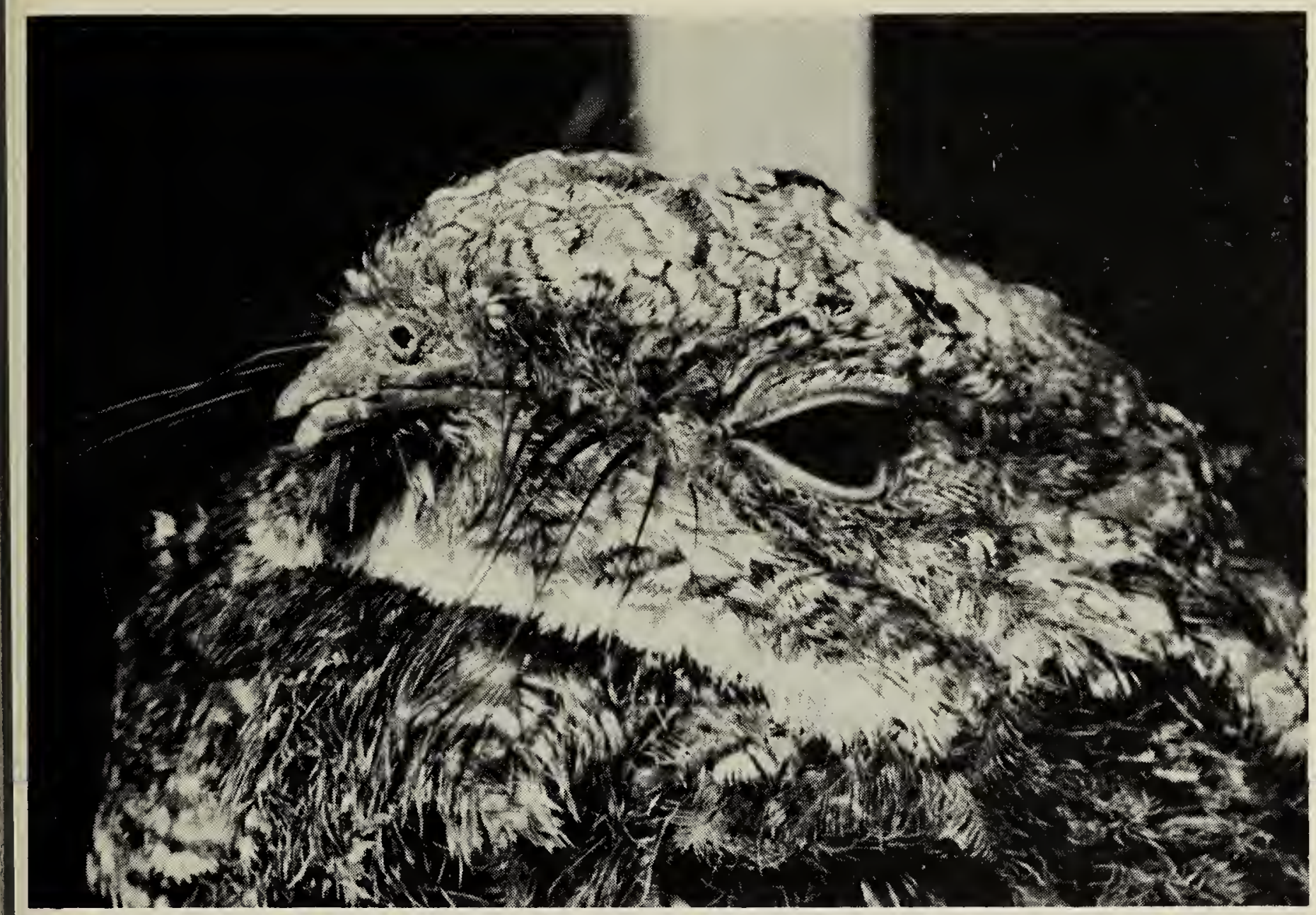

Photo by Loran L. Goulden

Poor-will showing beak and rictal bristles, June 24, 1972

a Poor-will in a torpid state in February when the temperature range was $22-56^{\circ} \mathrm{F}$ and Thorburg (1953) mentions finding another "hibernating" Poor-will in the Silverbell Mountains northwest of Tucson, Arizona, where the temperature was $73^{\circ} \mathrm{F}\left(23^{\circ} \mathrm{C}\right)$ on January 5 , the day it was found. Brauner (1952) began a series of experiments to test the reactions of Poorwills to light and temperature in an attempt to discover why the Poor-will "hibernates." His captive bird did not become torpid as a result of low temperature $36.5^{\circ} \mathrm{F} \quad\left(3^{\circ} \mathrm{C}\right)$, shortened days with or without reduced temperatures, nor as a result of reduction in diet. He found that it moved about at the end of twilight and again just before dawn but remained stationary the rest of the time. The bird in its wild state has been observed to react in the same way as it goes about gathering insects during the twilight and dawn hours. Marshall (1955), in his study of hibernation in captive goatsuckers, found that dormancy was not caused directly by low environmental temperature but by a lack of food. The birds did not become torpid until they were denied food and had lost 20 per cent of their weight. The captive Poor-will in Bartholomew et al. (1957) was fed Tenebrio (meal worm) larvae, beef heart, and lettuce and placed in a regulated air temperature; when the temperature dipped below $38^{\circ} \mathrm{F}$ $\left(3.5^{\circ} \mathrm{C}\right)$, it became torpid and aroused when the temperature was raised to $72^{\circ} \mathrm{F}\left(22^{\circ} \mathrm{C}\right)$.

The Poor-will's normal food is made up of moths, beetles, chinch bugs and locusts-that is, mostly smaller, nightflying insects but also some picked up on the ground (Bent, 1940). The Hostvedts began feeding their Poor-will bits of hamburger but, after consulting Dr. D. A. Boag of the Zoology Department of the University of Alberta, added some barley chop to this, to substitute for the roughage normally obtained from the wings and hard coverings of the insects. It lived quite contentedly on this diet until late 
June when it appeared sick, but visibly improved when it was fed insects that were gathered around the farm. Its plumage, however, became quite greasy and matted probably as a result of excess fat in the hamburger diet. Dr. Boag suggests that since the bird was kept in the kitchen near the stove where foods were being fried, it could have picked up the greasy condition from its environment. The condition of the plumage improved also with the addition of insects to its diet.

During the first few days of its captivity, the Hostvedts' Poor-will hissed, fluffed up its feathers, raised its wings, and opened its mouth wide when it was approached. Throughout this period it was fed by forcing open its mouth and cramming food into its throat. After these first few days the bird calmed down and began feeding itself. The Hostvedts placed the food on the side of an index finger and brought it near the bird which, after determining the food's position, then grabbed it with its mouth and swallowed it. During
March the Hostvedts' daughter Pat, who does not normally live at home, stayed at home alone with the bird; when she tried to feed it, the bird reverted to its old ways of hissing and showed its defence posture but after some time calmed down and accepted food. On one occasion when it attempted to seize the food, missed it and grabbed the end of Pat's finger, it apparently became confused and flew away to its normal resting place beneath the stove. Another amazing thing occurred at this point when the Hostvedts returned home. The bird perked up, began "chucking", and became excited in a way similar to that of a dog when its master greets him.

It was noted that the bird lost a few feathers throughout the winter and regrew them, but a much heavier loss occurred throughout February with no apparent change in the bird's activity. Just after he found the bird, Mr. Hostvedt noticed a scab-like formation on the upper mandible of the bird, which he removed without diffi-

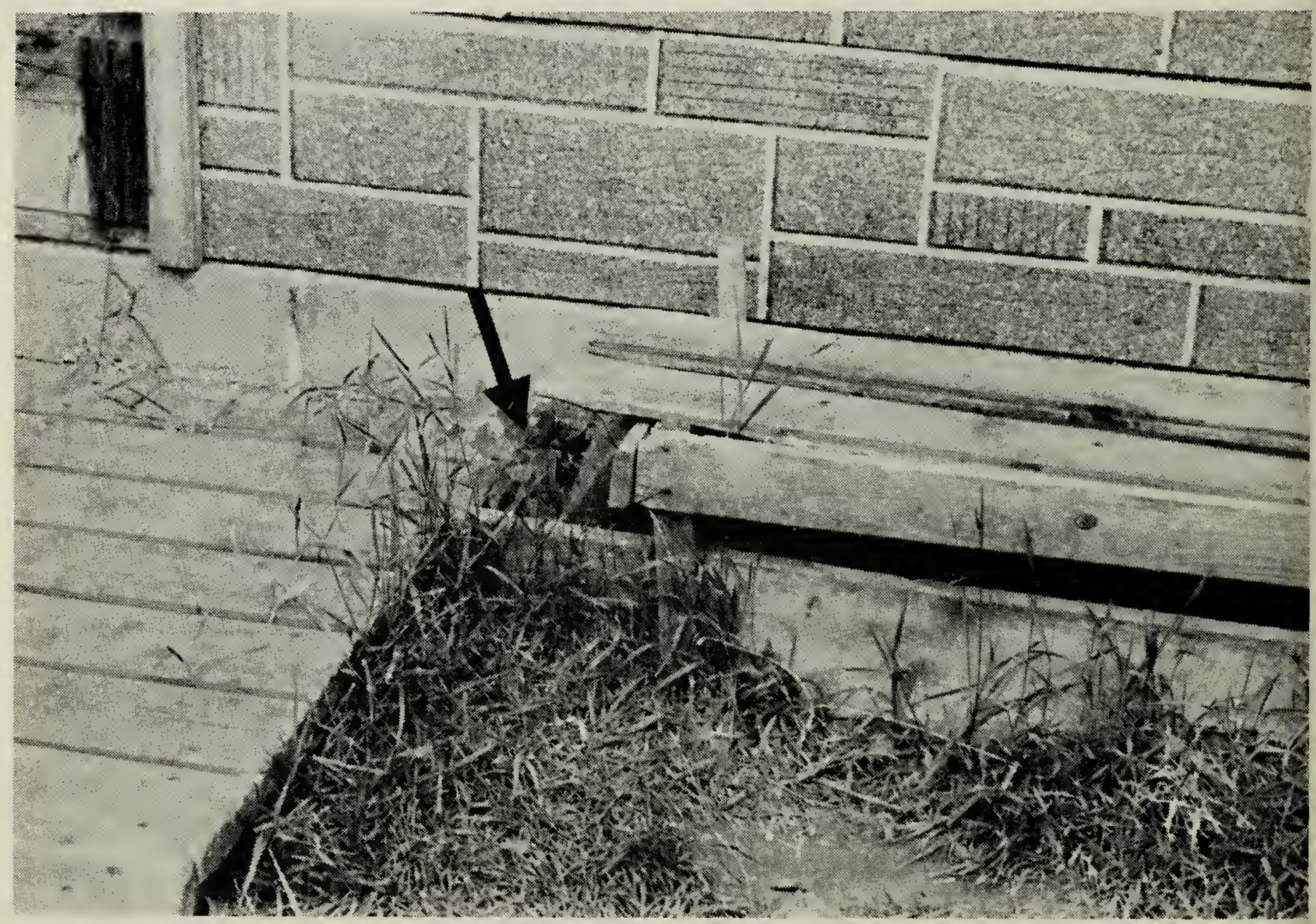

Photo by Loran L. Goulden

Doorstep of the Hostvedt home with arrow showing where the Poor-will was found. 
culty. However, the bill grew in an abnormal manner and became twisted similar to that of a Crossbill (Loxia sp.). This anomaly disappeared when a more normal upper mandible grew in during the latter part of June.

The Poor-will bathed regularly in a pan of sand placed for this purpose. Though water had been offered, the bird never accepted a drink, apparently obtaining sufficient moisture from its food. The bird was placed in a box at night so that it would not. injure itself and was exercised (prodded to fly) each morning and evening.

It began to give its normal call at night about the end of January. Jaeger (1953) observed that Poorwills start calling in late February or mid-March in California. If a person's hand approached the Poor-will from above, the bird appeared quite frightened but it reacted less violently to a hand below its eye level. If picked up and held it would try to escape, but if it was placed on the other hand, it would remain there with no attempt to escape. Furthermore, when the bird sat in the sunlight of the kitchen window, it allowed people in the kitchen to approach it without alarm, but if someone came near the window from the outside the bird would raise its wings, hiss and rock from side to side. The Hostvedts released the Poorwill on July 12, 1972 near the Coldstream ranch just a few miles southeast of Vernon, B.C. This locality was selected because Poor-wills are commonly seen and heard in the area. It was raining on the day it was released but when last seen the bird was sitting apparently quite content and alert on a dry branch.

We can only hope that it readapted to its normal environment and that it flew south with others of its kind in the fall.

\section{Acknowledgments}

I wish to thank Mr. and Mrs. John Hostvedt of Lindberg and Pat Hostvedt of Edmonton for allowing me to ise their observations and write about them. Thanks are due also to Dr. D. A. Boag for his suggestions.

\section{LITERATURE CITED}

American Ornithologists' Union 1957. Checklist of North American birds. Fifth ed. $691 \mathrm{pp}$.

Bard, F. G. 1961. First Poor-will specimen for Saskatchewan taken. Blue Jay, 19:172.

Bartholomew, G. A., T. R. Howell, and T. J. Cade. 1957. Torpidity in the White-throated Swift, Anna Hummingbird, and the Poorwill. Condor, $59: 145-155$.

Beck, W. H. 1965. Second Poor-will specimen for Saskatchewan. Blue Jay, $23: 82$.

Bent, A. C. 1940. (Dover ed. 1964), Life histories of North American cuckoos, goatsuckers, hummingbirds and their allies, part 1. U.S. Nat. Mus. Bull. No. 176. 244 pp.

Brauner, J. 1952. Reactions of Poor-wills to light and temperature. Condor, $54: 152-159$.

Brauner, J. 1953. Observations on the behavior of a captive Poor-will. Condor, 55:68-74.

Culbertson, A. E. 1946. Occurrences of Poorwills in the Sierran Foothills in winter. Condor, $48: 158-159$.

Elliott, C. 1966. An extension of the known range of the Poor-will in Saskatchewan. Blue Jay, $24: 7-8$.

Godfrey, W. E. 1966. The birds of Canada. Nat. Mus. Can. Bull. No. 203, Biol. Ser. No. 73 Ottawa, 428 pp.

Jaeger. E. C. 1948. Does the Poor-will "hibernate"? Condor, $50: 45-46$.

Jaeger, E. C. 1949. Further observations on the hibernation of the Poor-will. Condor, 51:105-109.

Jaeger, E. C. 1953. Poor-will sleeps away the winter. Nat. Geog. Mag., $103: 273-280$.

Lister, R. 1972. Whip-poor-will now a houseguest. Edmonton Journal, Jan. 20, p. 26.

Marshall, J. T., Jr. 1955. Hibernation in captive goatsuckers. Condor 57:129-134.

Reilly, E. M., Jr. 1968. The Audubon illustrated handbook of American birds. Edited by O. S. Pettingill, Jr., McGraw-Hill Book Co., New York, 524 pp.

Salt, W. R., and A. L. Wilk. 1966. The birds of Alberta. Second (revised) edition. Dept. Ind. \& Dev., Gov't of Alberta, Edmonton, $511 \mathrm{pp}$.

Thorburg, F. 1953. Another hibernating Poorwill. Condor, $55: 274$.

\section{SASKATCHEWAN CHRISTMAS BIRD COUNT 1972}

List the number of each bird species seen on the One Best Day from Saturday, December 16, 1972, through Monday, January 1, 1973, inclusive. In addition, list number of individuals of other species observed during the above dates (giving date for each).

See March 1972 Blue Jay for examples.

Send reports before January 15 , 1973 , to Mrs. Mary Houston, 863 University Drive, Saskatoon. 